\title{
Gezonde School: landelijke samenwerking voor een gezonde jeugd
}

\author{
Marije van Koperen · Vivian Kruitwagen · Arianne Westhuis · Martijn Sobels
}

(C) The Author(s) 2020

\begin{abstract}
Samenvatting Onderwijs maakt deel uit van de samenleving en bereidt leerlingen voor op participatie in de samenleving. Het stimuleren van een gezonde leefstijl bij leerlingen vormt een belangrijke maatschappelijke opdracht voor het onderwijs. Een gezonde leefstijl draagt immers bij aan het goed doorlopen van de schoolcarrière, een goede start van het werkend bestaan en op lange termijn een gezonder en langer leven. Scholen in het basis-, voortgezet- en middelbaar beroepsonderwijs kunnen met behulp van het nationale programma Gezonde School integraal en structureel werken aan een gezonde leefstijl, zodat een gezonde leefstijl op school vanzelfsprekend wordt. Samenwerking met landelijke thema- en kennis instituten, het onderwijs en de overheid is hierbij noodzakelijk, evenals de ondersteuning van GGD'en.
\end{abstract}

Trefwoorden gezonde leefstijl $\cdot$ school $\cdot$ landelijk beleid $\cdot$ leerlingen

\section{Healthy School: national cooperation for a healthy youth}

\begin{abstract}
Stimulating a healthy lifestyle among students is an important social task for education. After all, a healthy lifestyle contributes to the successful completion of the school career, a good start to working life and achieving health benefits. The Dutch Healthy School Programme supports schools in primary, secondary and secondary-vocational education to work integrally and structurally on a healthy lifestyle. The goal is to have a healthy lifestyle in the DNA of the schools.
\end{abstract}

dr. M. van Koperen $(\bowtie) \cdot$ dr. V. Kruitwagen · mr. A. Westhuis · M. Sobels

Programma Gezonde School, RIVM, Bilthoven, Nederland marije.van.koperen@rivm.nl
Keywords Healthy lifestyle $\cdot$ School $\cdot$ National policy $\cdot$ Students

\section{Opzet van het huidige programma Gezonde School}

Tussen 2012-2016 werd het programma Gezonde School (GS) gefinancierd vanuit het ministerie van Volksgezondheid, Welzijn en Sport (VWS). In 2012 maakten 496 van de 7.200 instellingen van het primair onderwijs (po) gebruik van een advies-op-maattraject en een ondersteuningsaanbod. In 2013 en 2014 werden opnieuw ondersteuningsrondes georganiseerd, ook voor het voortgezet onderwijs (vo) en het middelbaar beroepsonderwijs (mbo). Na drie rondes had $21,6 \%$ van alle scholen (ongeveer 8.400 po-, vo- en mbo-instellingen) een of meer keren ondersteuning aangevraagd [1]. Eind 2014 werden 124 vignetten Gezonde School uitgereikt, waardoor deze scholen zich Gezonde School mochten noemen [1]. Medio 2016 hadden ruim 750 scholen een vignet aangevraagd en was het aantal bezoekers van de website verviervoudigd naar 1.600 per week [1]. In diezelfde periode lanceerde ook het ministerie van Onderwijs, Cultuur en Wetenschap (OCW) enkele beleidsinitiatieven waarbij gezondheidsbevordering een belangrijke rol speelde, zoals de Onderwijsagenda Sport, Bewegen en Gezonde Leefstijl, de Gezonde Schoolpleinen, de Jeugdimpuls en het leerplankader van de Stichting Leerplankader Ontwikkeling.

De resultaten van deze fase van agenderen en stimuleren hebben ertoe geleid dat de ministeries van VWS, OCW, Economische Zaken (EZ) en Sociale Zaken en Werkgelegenheid (SZW) medio 2016 aan de toenmalige stuurgroep Gezonde School hebben gevraagd om tot een nieuw programma GS te komen voor 2017-2020. Dit plan werd geschreven door de PO-Raad, VO-raad en MBO-raad, het RIVM en GGDG- 
HOR-Nederland. Ook landelijke thema-instituten, samenwerkende gezondheidsfondsen (SGF) en andere organisaties die zich richten op een gezonde jeugd zijn indertijd betrokken geweest bij deze planvorming [2]. De missie van het programma GS 2017-2020 was de volgende: 'Een gezonde leefstijl is opgenomen in het DNA van elke school.' Sinds 2017 werken de onderwijsraden, GGDGHOR-Nederland en het RIVM samen in één programmaorganisatie met één programmaplan om deze missie te realiseren.

Om de diverse implementatie- en procesdoelen uit het programmaplan te realiseren worden verschillende projecten uitgevoerd: Ondersteuningsaanbod, Deskundigheidsbevordering, Gezonde School-aanpak, Vignet Gezonde School, Communicatie, Samenhang en aansturing, en Monitoring en evaluatie [2]. Deze projecten zijn verdeeld onder de vijf partners. Door middel van regulier overleg worden doelen en uitvoering op elkaar afgestemd. Daarnaast zijn meer dan veertig organisaties uit het onderwijs, overheidsinstellingen en maatschappelijke organisaties werkend op het brede vlak van gezondheidsbevordering aangesloten bij Gezonde School [2].

\section{De Gezonde School-aanpak}

Gezonde School helpt scholen met het stimuleren van een gezonde leefstijl. Centraal hierbij staat een planmatige en integrale werkwijze: de Gezonde Schoolaanpak [3]. Deze is gebaseerd op de Schoolslag-werkwijze (zie de bijdrage van Jansen en Leurs [4] in dit nummer). De aanpak is flexibel en aan te passen aan behoeften en mogelijkheden van de school. Overeenkomstig internationale inzichten omtrent school health promotion [5] staan vier pijlers centraal in de aanpak: 1) signalering, 2) educatie, 3) schoolomgeving en 4) beleid. Aan de hand van een stappenplan kunnen scholen gestructureerd aan de slag met een of meer thema's, waarbij de inzet van een Gezonde School (GS)-coördinator binnen de school wordt aanbevolen, naast contact met een Gezonde School (GS)adviseur van de GGD ter ondersteuning van de GSaanpak. De aanpak biedt scholen zo houvast bij het werken aan een gezonde leefstijl en helpt bij het structureel en integraal inbedden ervan op school.

\section{Vignet Gezonde School}

Door recente wetenschappelijke inzichten te vertalen naar de praktijk én door het programma en haar producten te monitoren en evalueren wordt de Gezonde School-aanpak continu doorontwikkeld en blijft de kwaliteit van het programma hoog. De thema's van Gezonde School zijn: voeding, bewegen en sport, roken, alcohol en drugs, welbevinden, relaties en seksualiteit, milieu en natuur/binnenmilieu en fysieke veiligheid. Die thema's krijgen, met behulp van de landelijke thema-instituten inhoudelijk vorm. Binnen de thema's worden erkende activiteiten aangereikt, die onderwijs- en themaspecifiek zijn [6]. Om scholen te helpen op de juiste wijze aan de thema's te werken zijn samen met de thema-instituten kwaliteitseisen opgesteld. Wanneer scholen aan deze minimale kwaliteitseisen voldoen, kunnen zij een themacertificaat aanvragen, dat wordt beoordeeld door de thema-instituten. Met het behalen van het themacertificaat heeft de school het vignet Gezonde School verdiend. Een school mag zich dan voor drie jaar Gezonde School noemen.

\section{Ondersteuningsaanbod Gezonde School}

Om scholen te helpen planmatig en structureel met Gezonde School te werken, kunnen ze het Ondersteuningsaanbod aanvragen. De scholen ontvangen dan een bedrag van $€ 3.000$,- om een erkende activiteit aan te schaffen of taakuren van de GS-coördinator te vergoeden. Naast het geldbedrag kan de school gebruikmaken van 10 uur ondersteuning van een GSadviseur. Gezonde School richt zich op alle leerlingen en studenten, en in het bijzonder op kwetsbare leerlingen. Het gaat dan vooral om reguliere scholen in achterstandswijken en scholen in het speciaal onderwijs. Deze scholen krijgen voorrang bij de toekenning van het Ondersteuningsaanbod. De redenering hierachter is dat bij deze kwetsbare leerlingen de meeste gezondheidswinst te behalen is en de meeste ondersteuning nodig is.

Dat het programma groeit en er meer behoefte is aan ondersteuning bleek begin 2020 uit de eerste resultaten van het programma Gezonde School 2017-2020:

- Er zijn ruim 2.900 aanvragen voor het Ondersteuningsaanbod toegekend.

- Er zijn ruim 1.500 vignetaanvragen gedaan.

- Van alle po-, vo- en mbo-scholen mag $17 \%$ zich Gezonde School noemen.

- Jaarlijks zijn er 700 GS-coördinatoren die deskundigheidsbevordering krijgen.

- Er zijn 61 erkende interventies beschikbaar voor het po, 57 voor het vo en 22 voor het mbo.

- Er zijn inmiddels elke maand 9.900 unieke bezoekers voor gezondeschool.nl.

De groei gaat echter langzaam en niet alle scholen worden bereikt. Structurele borging van aandacht voor gezondheid en gezonde leefstijl in het onderwijs blijft een belangrijk vraagstuk voor de landelijke en gemeentelijke overheid. Ondanks de theoretische onderbouwing en de toename van scholen die het Ondersteuningsaanbod of een vignet aanvragen is er nog onvoldoende wetenschappelijk bewijs voor de effecten op de individuele gezondheid van leerlingen [7]. Vorig jaar is op verzoek van ZonMW een onderzoek gestart naar de effecten van het programma Gezonde School. In twee promotieonderzoeken wordt niet alleen gekeken naar de effecten op leerlingniveau, maar ook naar de processen en effecten op organisa- 
tie- en implementatieniveau. Denk bijvoorbeeld aan gemeentelijk en landelijk ondersteunend beleid (zie de bijdrage van Vennegoor et al. in dit nummer [8]).

\section{Samenwerking}

De aandacht vanuit de politiek en maatschappij voor een gezonde leefstijl neemt al jaren sterk toe. Dit heeft ertoe geleid dat Gezonde School ook een aantal additionele regelingen uitvoert. Uit het Nationaal Preventieakkoord kwam bijvoorbeeld de subsidieregeling 'Watertappunten' voort. Basisscholen kunnen via deze regeling een tegemoetkoming krijgen voor de aanschaf en het onderhoud van een watertappunt op het schoolplein. Ook voert Gezonde School de subsidieregeling 'Jong Leren Eten - lekker naar buiten!' uit. Deze regeling is een initiatief van het Ministerie van Landbouw, Natuur en Voedselkwaliteit, waarbij scholen subsidie kunnen aanvragen voor moestuinieren, koken of een excursie/gastles op het gebied van voeding. Het Regeerakkoord heeft in 2019 de stimuleringsregeling Gezonde Relaties \& Seksualiteit voortgebracht. De komende jaren voert Gezonde School deze regeling uit, waarbij scholen worden gestimuleerd om aandacht te besteden aan relaties en seksualiteit om seksuele gezondheid te bevorderen en zo bij te dragen aan het voorkomen van onbedoelde (tiener)zwangerschappen. Gezonde School kan deze regelingen uitvoeren omdat het inmiddels hét kanaal is naar scholen en de infrastructuur heeft gerealiseerd om scholen te bereiken met een boodschap over gezondheidsbevordering en ze te helpen deze op school een structurele plek te geven.

Belangrijk voor een nationaal programma en de uitvoering van stimuleringsregelingen is continue afstemming met andere landelijke initiatieven gericht op de gezonde jeugd. Denk aan JOGG, Alles is Gezondheid, Gezonde Generatie, Sport en Bewegen in de Buurt en het programma Jong Leren Eten. Dat gebeurt op zowel nationaal als lokaal niveau, waar JOGG-regisseurs, JLE-makelaars en de GS-adviseurs elkaar weten te vinden. Met het oog op borging is ook samenwerking met docentenopleidingen belangrijk. Zo kon dankzij onder andere de pabo in Leiden de opleiding 'Specialist Sportieve en Gezonde School' starten en is onlangs groen licht gegeven voor een verkenning bij eerste- en tweedegraads docentenopleidingen. Dergelijke opleidingen gaan zorgen voor meer docenten met kennis over gezondheidsbevordering en de Gezonde School-aanpak. Andere winsten waar Gezonde School niet direct een bijdrage aan heeft geleverd, maar waaruit wel blijkt dat de school als setting essentieel is in het laten opgroeien van een gezonde generatie zijn bijvoorbeeld de per medio 2020 verplichte rookvrije schoolterreinen en de onlangs toegekende motie om op basisscholen 120 minuten in plaats van 90 minuten bewegingsonderwijs per week verplicht te stellen.

\section{Doorontwikkeling van Gezonde School}

Het programma Gezonde School is en blijft een vraaggestuurd programma. De vraag van het onderwijs en de nieuwste wetenschappelijke inzichten op het gebied van gezondheidsbevordering staan centraal bij de invulling van het programma. Het programma is daardoor continu in beweging. Volgend jaar gaat het nieuwe programmaplan Gezonde School 2021-2024 van start. Wederom hebben vele partijen meegedacht met de invulling. Hierin worden onder andere meegenomen: mogelijkheden van Curriculum.nu, inzichten uit recente Nederlandse onderzoeken (zie de bijdragen van Renders et al. [9], en van Bartelink et al. in dit nummer [10]), inzichten uit het buitenland, zoals de IJslandse aanpak, en ontwikkelingen vanuit de bredere maatschappelijke context, bijvoorbeeld aandacht voor duurzaamheid en milieu voortkomend uit de beleidsdoelstelling 'Nederland Circulair in 2050'.

Uit gesprekken met GS-coördinatoren en GS-adviseurs klinkt het verlangen om het Gezonde Schoolaanbod en de daarvoor benodigde processen beter aan te laten sluiten bij de (organisatorische) mogelijkheden van het onderwijs. De toegenomen werkdruk in het onderwijs kan immers een weerslag hebben op de mogelijkheden om regelingen aan te vragen en uit te voeren. De processen van Gezonde School moeten daar dus beter op aansluiten. Deze uitdaging geldt in toenemende mate voor het speciaal onderwijs. Een onlangs gehouden verkenning gaf inzicht in de wensen en behoeften van het speciaal onderwijs. Het programma Gezonde School ziet daarop verbetermogelijkheden voor het activiteitenaanbod, webbased informatie en ondersteuning. Het programma wil daarnaast de aankomende jaren de mogelijkheden verkennen om de huidige integrale aanpak gericht op leefstijlveranderingen bij leerlingen en studenten te verruimen naar schoolmedewerkers. Ook samenwerking en afstemming met het programma Gezonde Kinderopvang blijven belangrijk. Kinderen vinden een gezonde leefstijl vanzelfsprekend als zij zich eerst op het kinderdagverblijf en daarna op de lagere school en de naschoolse opvang in een omgeving bevinden die structureel aandacht heeft voor gezondheid en een gezonde leefstijl. Daarnaast zien we een trend in het buitenland om well-being de basis op scholen te laten zijn. In Nederland is dit het beste te vertalen naar een positief pedagogisch schoolklimaat. Zonder deze veilige basis is het moeilijk werken aan thema's als relaties en seksualiteit of alcohol en drugspreventie. Ook dit zal als beleidsuitgangspunt terugkomen in het nieuwe programmaplan.

Gezonde School verkent en definieert elementen die een belangrijke bijdrage leveren aan het inrichten van een gezonde leer-, leef- en werkomgeving voor leerlingen, studenten en werknemers in het onderwijs, en een gezonde leefstijl ondersteunen, en biedt scholen hier ondersteuning bij. Maar de inzet van de Gezonde School-aanpak is voor scholen wellicht nog 
te vrijblijvend. Gezonde School maakt kennis over werkzame onderdelen beschikbaar, zodat lokale en landelijke beleidsmakers met deze kennis vanuit hun verantwoordelijkheid beter kunnen bijdragen aan een gezonde jeugd. Ook daar zal de komende jaren sterker op ingezet moeten gaan worden, zodat in Nederland gezondheid écht in het DNA van elke school zit en wij onze jeugd die randvoorwaarden kunnen bieden om zich optimaal te ontplooien, om later in het arbeidsproces te participeren en een leven lang fit en gezond blijven.

Open Access This article is licensed under a Creative Commons Attribution 4.0 International License, which permits use, sharing, adaptation, distribution and reproduction in any medium or format, as long as you give appropriate credit to the original author(s) and the source, provide a link to the Creative Commons licence, and indicate if changes were made. The images or other third party material in this article are included in the article's Creative Commons licence, unless indicated otherwise in a credit line to the material. If material is not included in the article's Creative Commons licence and your intended use is not permitted by statutory regulation or exceeds the permitted use, you will need to obtain permission directly from the copyright holder. To view a copy of this licence, visit http://creativecommons.org/licenses/by/4.0/.

\section{Literatuur}

1. Hoogendoorn M, A D van der, Bemelmans W. Meer doen met gezondheid op school. Tijdschr Gezondheidswet. 2015;93(8):290-4.

2. Gezonde School. Gezonde school programma 2017-2020. 2016. https://www.rijksoverheid.nl/documenten/rappor ten/2016/12/13/gezonde-school-programma-2017-2020. Geraadpleegd op 3 juni 2020.

3. Gezonde School. Wat is Gezonde School? 2020. https:// www.gezondeschool.nl/aanpak/wat-is-gezonde-school. Geraadpleegd op: 8 mei 2020.

4. Jansen M, Leurs M. Regionale en landelijke innovaties. TSG - Tijdschrift voor gezondheidswetenschappen (in press)

5. World Health Organization. What is a health promoting school? 2020. https://www.who.int/school_youth_health/ gshi/hps/en/. Geraadpleegd op: 26 feb 2020.

6. Erkende Gezonde School activiteiten per onderwijssector te vinden op https://www.gezondeschool.nl/primaironderwijs/interventies-primair-onderwijs; https://www. gezondeschool.nl/voortgezet-onderwijs/gezonde-schoolactiviteiten; https://www.gezondeschool.nl/middelbaarberoepsonderwijs/gezonde-school-activiteiten. Alle geraadpleegd op 16 mei 2020.

7. Langford R, Bonell CP, Jones HE, et al. The WHO Health Promoting School framework for improving the health and well-being of students and their academic achievement. Cochrane Database Syst Rev. 2014; https://doi.org/10. 1002/14651858.CD008958.pub2.

8. Vennegoor G, Vonk L, van Assema P et al. Onderzoeksopzet evaluatie Gezonde School: onder welke condities doet het ertoe? Tijdschr Gezondheidswet. 2020. https://doi.org/10. 1007/s12508-020-00276-6

9. Renders C, van Dongen B, de Vries I et al. FLASH: vmboleerlingen overhet creëren van een gezondeschoolgemeenschap. Tijdschr Gezondheidswet. 2020. https://doi.org/10. 1007/s12508-020-00272-w

10. Bartelink N, van Assema P, Kremers S, Savelberg H, Jansen $\mathrm{M}$, De invloed van de schoolcontext op de effecten van de Gezonde Basisschool van de Toekomst. Tijdschr Gezondheidswet. 2020. https://doi.org/10.1007/s12508020-00274-8 